\title{
Tuberculosis, HIV seroprevalence and intravenous drug abuse in prisoners
}

\author{
F.A. Drobniewski*, Y.M. Balabanova*\#, M.C. Ruddy*, C. Graham ${ }^{\top}$, S.I. Kuznetzov ${ }^{+}$, \\ G.I. Gusarova ${ }^{+}$, S.M. Zakharova ${ }^{\S}$, A.S. Melentyev ${ }^{\dagger}$ and I.M. Fedorin"
}

ABSTRACT: High rates of tuberculosis (TB) and HIV are believed to exist in Russian prisons. Prisoners with TB were studied in order to identify the following: 1) prevalence of HIV, and risk factors for HIV and other blood-borne virus infections; and 2) clinical and social factors that might compromise TB treatment effectiveness and/or patient adherence and, hence, encourage treatment failure.

A 1-yr cross-sectional prevalence study of 1,345 prisoners with TB was conducted at an in-patient TB facility in Samara, Russian Federation.

HIV and hepatitis B and/or C co-infection occurred in $12.2 \%$ and $24.1 \%$ of prisoners, respectively, and rates were significantly higher than in civilians. Overall, $48.6 \%$ of prisoners used drugs, of which $\mathbf{8 8 . 3} \%$ were intravenous users. Prisoners were more likely to be intravenous drug users and HIV positive compared with civilians with TB, and $40.2 \%$ of prisoners shared needles. Two-thirds of prisoners $(68.6 \%)$ had received previous TB drug therapy (frequently multiple, interrupted courses) and were significantly more likely than civilians to have had previous therapy consistent with the high drug-resistance rates seen.

Prisons are major drivers of the tuberculosis and HIV epidemics. Novel strategies are needed to reduce the spread of blood borne diseases, particularly in intravenous drug users.

KEYWORDS: HIV, intravenous drug users, prisons, Russia, tuberculosis

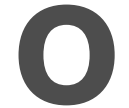
ne of the world's fastest-growing HIV epidemics is occurring in Russia. By mid 2004, 283,000 individuals were reported as HIV positive [1], equivalent to a prevalence of 136 per 100,000 people [2]. In 2003, there was also a significant rise in tuberculosis (TB) incidence and mortality [3] to 83.0 per 100,000 and 22.0 per 100,000 , respectively [4, 5]. High rates of drugresistant $\mathrm{TB}$ and multiple drug-resistant $\mathrm{TB}$ (MDRTB) have been reported from former countries of the USSR [6-11]. Unfortunately, the $\mathrm{HIV}$ and TB epidemics are now converging in Russia [12].

Globally, prisons have shown some of the highest concentrations of TB, viral hepatitis and HIV; for example, worldwide, it is estimated that HIV infection is 75-times higher in prisoners than among civilian population [13]. The Russian Federation has one of the highest incarceration rates in the world, with nearly $1 \%$ of the population kept in prisons [14], and $\sim 350,000$ people leaving prisons annually. Many of the released prisoners have TB that has only been partially treated, but, frequently, ex-prisoners do not register with the civilian medical service and, therefore, fail to continue their treatment. The high rates of treatment interruption are a major factor associated with drug resistance. Russian prisons are sites of poor health. In 2002, of 905,000 prisoners in Russia, 405,000 were ill and 90,000 of these had TB, 102,000 were drug addicts and 72,000 were alcoholics [15].

Samara is one of 89 regions in Russia, with a population of 3.3 million. Although an economically advanced region, it is a site of a rapidly expanding HIV epidemic, with 22,424 registered cases in mid $2004[16,17]$. In 2003, the corresponding new $\mathrm{TB}$ cases and mortality rates were 74.9 per 100,000 and 12.3 per 100,000 , respectively $[18,19]$. TB is also a major problem in Samaran prisons, with a TB incidence rate of 2,200 per $100,000[18,19]$. Over 400 cases of co-infection with TB and HIV had been reported by mid 2004 in Samara.

The current authors performed the largest systematic cross-sectional study of Russian prisoners with TB to date, with the aim of: 1) establishing the prevalence of HIV co-infection; 2) identifying risk factors for concurrent HIV infection, for noncompletion or poor adherence of treatment; and 3) producing a detailed demographic, clinical
AFFILIATIONS

*HPA National Mycobacterium Reference Unit, Dept of Microbiology and Infection, King's College London, London, and

Epidemiology and Statistics Core, Wellcome Trust Clinical Research Facility, Edinburgh, UK.

\#Samara TB Service, Samara Oblast Dispensary,

${ }^{+}$Samara Oblast Health Dept,

${ }^{\text {s} S a m a r a ~ C i t y ~ T B ~ S e r v i c e, ~ a n d ~}$

${ }^{\text {f }}$ Samara Prison TB Service, Samara

City, Russian Federation.

CORRESPONDENCE

F.A. Drobniewski

HPA MRU

Dept of Microbiology and Infection King's College Hospital (Dulwich)

East Dulwich Grove

London SE22 8QF UK

Fax: 442073466477

E-mail: francis.drobniewski@kcl.

ac.uk.

Received:

November 292004

Accepted after revision:

February 282005

SUPPORT STATEMENT

This study was conducted with the financial support of the Dept for International Development, London, UK (CNTR 00 0134), and the European Respiratory Society (Y.M. Balabanova is the recipient of a European Respiratory Society Fellowship).

European Respiratory Journal Print ISSN 0903-1936 Online ISSN 1399-3003 
and social profile of TB patients. It was hoped that this analysis would help to define the appropriate public health action, aiming to reduce HIV and blood-borne virus transmission, and improve TB treatment for prisoners in the Russian penitentiary services and elsewhere in the industrialised world.

\section{METHODS}

Patients with pulmonary TB were recruited from the prison TB hospital colony over 1 yr from November 2001 to October 2002. The TB hospital colony is an in-patient facility that diagnoses and admits all $\mathrm{TB}$ cases from the prison sector for treatment. TB in prisoners is diagnosed using a combination of radiological screening (on admission and then every 6 months), microscopy and bacteriological culture. Consecutive patients aged $>18$ yrs were invited to take part on arrival at the TB hospital colony, gave informed written consent, and were interviewed by a team of trained Russian nurses using a structured questionnaire. All TB patients were routinely tested for HIV and hepatitis B and C. Over the same time period, 1,522 civilian males with pulmonary TB were interviewed using the same questionnaire to further identify particular features related to prisoner-associated TB compared with males in civil society. Civilian males were drawn from all 18 civilian TB dispensaries across the region, in proportion to the number of new $\mathrm{TB}$ cases contributed annually by each dispensary. The questionnaire and study was developed and approved by the Federal Tuberculosis Institutions (Moscow), Samara TB service, Samara Ethics Committee, and the Samara Regional Health Dept, under whose auspices the study was conducted. Questionnaire-derived demographic (e.g. age, sex, ethnicity, housing), clinical and social data (e.g. sexually transmitted diseases, HIV and hepatitis status, bacille Calmette-Guérin (BCG) vaccination, TB contact and treatment history) were verified using the medical notes. The sexual health section of the questionnaire was completed using previously established methodology [20, 21]. Radiological reports were analysed descriptively (area of lungs affected and presence of cavities).

Comparative analyses against all variables were conducted between HIV-positive and -negative groups using Chi-squared and Mann-Whitney U-tests. From the univariate analysis, all variables that had a $p$-value of $\leqslant 0.1$ were included in a multivariate logistic regression analysis. The initial model contained all variables meeting this criterion, with nonsignificant variables removed sequentially until only statistically significant variables were included.

\section{RESULTS}

Questionnaires were completed and medical notes reviewed on 1,345 prisoners with TB across the region $(<2 \%$ refused to participate). Prisoners were nearly all male, principally of Russian ethnicity (83.3\%), had been BCG vaccinated $(98.8 \%)$ and had a median age of 31 yrs (range 21-39; table 1). Few had been homeless $(1.5 \%)$, but a large minority $(27.1 \%)$ had lived in poor communal housing before imprisonment. Some prisoners had previously been incarcerated on a number of occasions, as follows: once $(1.5 \%)$, twice $(19.2 \%)$, three times $(37.5 \%)$ and four times $(25.1 \%)$.

\section{Clinical and social profile of prisoners compared with civilians}

The principal clinical features of the prisoners interviewed are given in table 1 and were typical of those with pulmonary TB. With the exception of a productive cough $(83.6 \%)$, fatigue $(79.7 \%)$ and shortness of breath $(52.7 \%)$, most features were exhibited by only a minority of patients, emphasising the importance of laboratory confirmation of TB. Prisoners, despite a widespread system of repeated fluorographic examination, were more likely to be symptomatic and have advanced disease (83.6\% had a productive cough and $48.2 \%$ had two damaged zones with/without cavities on their chest radiographs). Over two-thirds $(68.6 \%)$ had received previous TB drug therapy, which is a major risk factor for drug resistance. High rates of civilians and prisoners had received BCG vaccination.

Table 1 indicates the rates of HIV and principal blood-borne virus (hepatitis B or C) co-infection, previous history of sexually transmitted infections (STIs) and sexual practices for prisoners. The rate of co-infection with HIV was $6.0 \%$ overall (197 out of 3,279), but was significantly higher $(12.2 \% ; 164$ out of 1,344$)$ in prisoners compared with civilian TB patients $(1.7 \%$; 33 out of 1,935). The rate difference was $8.6-12.4 \%$, relative risk (RR) was 4.9-10.3 and the odds ratio was $5.47-11.7$ between civilian and prisoner patients at a significance of $\mathrm{p}<0.001$.

Viral hepatitis was seen in $24.1 \%$ of prisoners, reflecting the high rates of jaundice observed (16.5\%). The rates of HIV and viral hepatitis were higher in intravenous drug users (IDUs) compared with prisoners who did not inject drugs, based on those answering the question on IDU (10.7\% (61 out of 568$)$ versus $11.1 \%$ (six out of 54 ), $\mathrm{p}<0.05$; and $34.1 \%$ (192 out of 563 ) versus $28.9 \%$ (22 out of 76 ), $\mathrm{p}>0.05$ ). Approximately $26.7 \%$ of prison patients had been infected with a STI.

Most patients started smoking early in life and alcohol consumption was high generally, which was reflected in the high rates of liver disease and jaundice, although $7.5 \%$ did not drink at all. Smoking and alcohol consumption were higher amongst prisoners compared with civilians with TB (table 2). Overall, $48.6 \%$ (648 out of 1,334) of prisoners used drugs, which was significantly higher than amongst civilian patients. Drug abuse amongst prisoners was primarily intravenous $(88.3 \%)$, with opiates as the preferred type of drug $(85.6 \%)$. Sharing needles was practiced by $40.2 \%$ of IDUs, with $3.1 \%$ using blood as a stabiliser material.

Overall, prisoners did not appear to be more economically disadvantaged than civilians, as although civilians were less likely to have owned their own flat previously, they were less likely to have lived in a "wooden house" (a traditional basic dwelling made of wood with no internal sanitation).

\section{Differences between HIV-positive and -negative TB patients} Prisoners with HIV and TB (table 3) co-infection were more likely to have fever ( $R R=1.55 ; 95 \%$ confidence interval (CI) 1.04-2.29), but were less likely to report weight loss $(R R=0.63$; $95 \%$ CI $0.43-0.92)$ or shortness of breath $(R R=0.62 ; 95 \% \mathrm{CI}$ $0.44-0.88$ ). They also reported a history of previous lung disease more frequently $(\mathrm{RR}=2.42 ; 95 \% \mathrm{CI} 1.54-3.83)$.

HIV-positive individuals were more likely to have previous liver disease (RR 4.90; 95\% CI 2.99-8.02), jaundice (RR 6.38; 


\begin{tabular}{|c|c|c|}
\hline \multirow{2}{*}{$\begin{array}{l}\text { TABLE } 1 \\
\text { Variable }\end{array}$} & \multirow[b]{2}{*}{$\begin{array}{l}\text { Responding } \\
\text { prisoners } \mathrm{n}\end{array}$} & \multirow[b]{2}{*}{ n (\%) } \\
\hline & & \\
\hline Sex & 1342 & \\
\hline Male & & $1327(98.9)$ \\
\hline Female & & $15(1.1)$ \\
\hline Age $^{\#}$ & 1336 & \\
\hline Ethnicity & 1333 & \\
\hline Russian & & $1111(83.3)$ \\
\hline \multicolumn{3}{|l|}{ Residence } \\
\hline Homeless & 1319 & $20(1.5)$ \\
\hline Own flat & 1334 & $910(68.2)$ \\
\hline Common flat & 1334 & $33(2.5)$ \\
\hline Hostel & 1334 & $10(0.8)$ \\
\hline Wooden house & 1333 & $360(27.1)$ \\
\hline Share accommodation with other adults & 1345 & $1173(87.2)$ \\
\hline Sharing with children & 1345 & $260(19.3)$ \\
\hline \multicolumn{3}{|l|}{ Clinical } \\
\hline Active pulmonary TB & 1336 & $1114(83.4)$ \\
\hline Productive cough & 1339 & $1119(83.6)$ \\
\hline Weight loss & 1335 & $420(31.5)$ \\
\hline Night sweats & 1336 & $370(27.7)$ \\
\hline Fever & 1332 & $277(20.8)$ \\
\hline Shortness of breath & 1338 & $705(52.7)$ \\
\hline Chest pain & 1335 & $652(48.8)$ \\
\hline Fatigue/weakness & 1338 & $1066(79.7)$ \\
\hline Contact with TB cases & 1338 & $551(41.2)$ \\
\hline $\mathrm{Home}^{+}$ & 1338 & $204(15.2)$ \\
\hline Workplace & 478 & $6(1.3)$ \\
\hline BCG vaccination & 1209 & $1195(98.8)$ \\
\hline \multicolumn{3}{|l|}{ Radiology zones affected } \\
\hline$\geqslant 2$ damaged zones & 1252 & $552(44.1)$ \\
\hline$\geqslant 2$ damaged zones and/or cavities & 1253 & $604(48.2)$ \\
\hline \multicolumn{3}{|l|}{ Treatment $^{\S}$} \\
\hline $\begin{array}{l}\text { Previous drug therapy or currently on } \\
\text { therapy for }>4 \text { weeks }\end{array}$ & 1339 & $1214(90.7)$ \\
\hline Surgical treatment & 1340 & $21(1.6)$ \\
\hline \multicolumn{3}{|l|}{$\begin{array}{l}\text { Sexually transmitted and blood-borne } \\
\text { infections }\end{array}$} \\
\hline HIV positive & 1344 & $164(12.2)$ \\
\hline Hepatitis B or C infection & 1327 & $320(24.1)$ \\
\hline Jaundice & 1337 & $221(16.5)$ \\
\hline Any STI & 1327 & $354(26.7)$ \\
\hline Gonorrhoea & 1323 & $85(6.4)$ \\
\hline Syphilis & 1327 & $116(8.7)$ \\
\hline Chlamydia & 872 & $4(0.5)$ \\
\hline Recreational drugs ${ }^{f}$ & 1334 & $648(48.6)$ \\
\hline Cocaine & 589 & $17(2.9)$ \\
\hline Marijuana & 600 & $116(19.3)$ \\
\hline Amphetamine & 589 & 7 (1.2) \\
\hline Opiate & 645 & $552(85.6)$ \\
\hline By injection & 642 & 567 (88.3) \\
\hline Injecting and sharing needles & 532 & $214(40.2)$ \\
\hline \multicolumn{3}{|l|}{ Smoking } \\
\hline Current smoker & 1339 & $1293(96.6)$ \\
\hline Cigarettes & 1292 & $632(81.8)$ \\
\hline Ex-smoker & 1304 & $21(1.6)$ \\
\hline
\end{tabular}

\begin{tabular}{|c|c|c|}
\hline \multicolumn{3}{|c|}{ TABLE 1} \\
\hline Variable & $\begin{array}{l}\text { Responding } \\
\text { prisoners } \mathbf{n}\end{array}$ & n (\%) \\
\hline Alcohol consumption $^{f}$ & 1339 & $1238(92.5)$ \\
\hline Every day & 1235 & $144(11.7)$ \\
\hline \multicolumn{3}{|l|}{ Social activities } \\
\hline Visiting saunas & 1325 & $775(58.5)$ \\
\hline Visit pubs/clubs & 1327 & $670(50.5)$ \\
\hline Visit church & 1156 & $41(3.5)$ \\
\hline \multicolumn{3}{|c|}{ 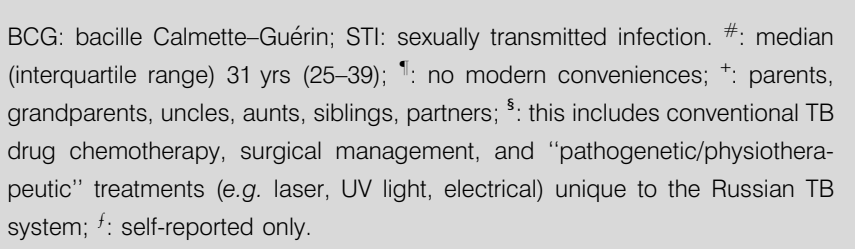 } \\
\hline
\end{tabular}

95\% CI 4.03-10.10), and concurrent hepatitis B or C infection (RR 2.13; 95\% CI 1.45-3.13) in the univariate analysis, with history of lung diseases and jaundice remaining significant in the multivariate analysis (odds ratio (OR) 2.17, 95\% CI 1.23 3.81; and OR 8.48; 95\% CI 4.86-14.80, respectively). Univariate analysis showed that prisoners with HIV and TB were also more likely to have been treated for TB previously (RR 1.44; 95\% CI 1.00-2.06) and to be on post-treatment anti-TB relapse therapy (RR 2.61; 95\% CI 1.43-4.75). Prisoners had received between one and 23 cycles of therapy.

\section{DISCUSSION}

This study is one of the largest (and the largest in Eastern Europe) population-based studies of TB patients with and without HIV infection. The study revealed worrying trends for those charged with the management of the HIV and TB epidemics in prisons. A high prevalence of HIV amongst prisoners with $\mathrm{TB}$, particularly those who were IDUs, was found, and the rate of HIV was significantly higher than in civilian patients.

In the Samaran $\mathrm{TB}$ colony, nearly half of the prisoners admitted recreational drug use, with many using and sharing needles, which explained the relatively high rates of HIV and hepatitis $\mathrm{B}$ or $\mathrm{C}$. The corresponding rates of HIV infection and intravenous drug use in 1,522 male civilians who were interviewed during the same time period were significantly lower at $2.4 \%$ and $3.3 \%$ (both $\mathrm{p}>0.05$ ), respectively. Other studies have demonstrated a widespread and early introduction to injecting drugs in civilian society, which must underpin the prison situation; for example, one study in Moscow showed that $4 \%$ of school children used drugs, some as young as $13-15$ yrs [22]. Intravenous drug use remains a problem within prisons across the industrialised world [13]; for example, in the UK, it is estimated that $24 \%$ of prisoners are IDUs, and, of those, $20 \%$ have hepatitis B and 30\% hepatitis C. In Norway, $28 \%$ of prisoners are imprisoned for drug-related offences [14].

The comparative analysis of TB patients co-infected with HIV and other TB patients supports the importance of intravenous drug abuse as the principal vector of HIV (and blood-borne 
TABLE 2 Significant differences in clinical, social and sexual health factors between male civilians and prisoners with tuberculosis

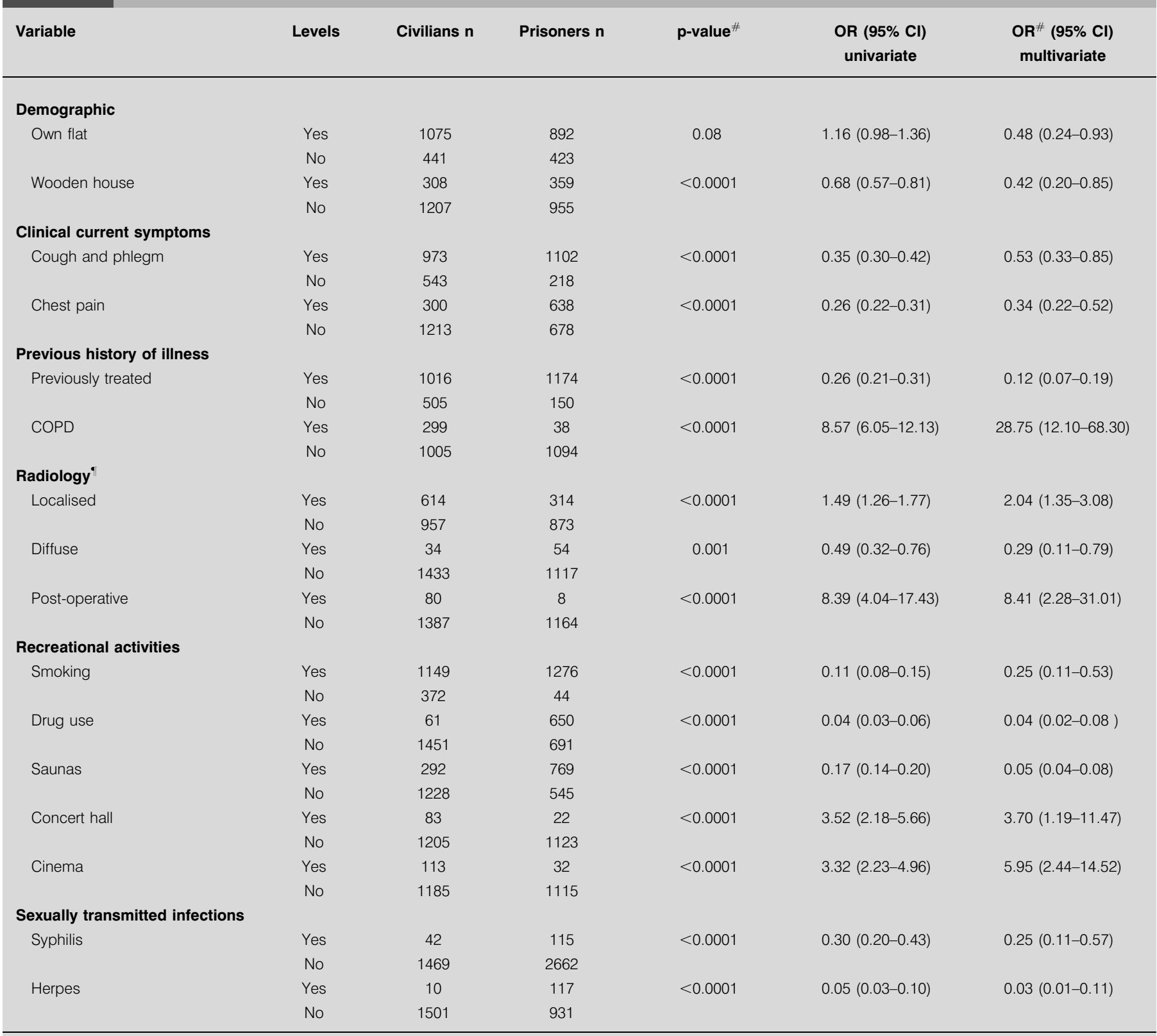

OR: odds ratio; Cl: confidence interval; COPD: chronic obstructive pulmonary disease. \#: statistically significant variables from univariate analysis included in final model;

$\because$ : includes pathological-based description (more typically used in Russian radiological description) and zone-based description.

viral spread). Higher rates of sexually transmitted diseases, such as gonorrhoea, amongst prisoners also suggest the increasing importance of STIs as a facilitator of HIV transmission in this group. Saunas are an important nonsexual social event for Russians of both sexes; traditionally, the steam produced has been considered to be helpful for respiratory illnesses, and this may help to propagate and spread bacilli.

High rates of multiple drug resistance have been reported in Samara, particularly within the prison TB colony [23]. The overall prevalence of isoniazid, rifampicin, streptomycin, ethambutol and pyrazinamide resistance amongst TB cases in prisoners was $62.7 \%, 37.3 \%, 71.4 \%, 33.3 \%$ and $13.0 \%$, respectively. The prevalence of MDRTB in new prison cases was $37.3 \%$ [24], nearly twice as high as the rate among civilian TB patients.

There have been problems with maintenance of the drug supply, which, together with limited access to high-quality, fixed-dose combination drugs, leads to frequent changes of drug therapy and relatively poor continuity of treatment. The higher probability of both underlying (alcohol, viral hepatitis, etc.) and TB treatment-related hepatotoxicity in this group reinforces potential underdosing and the development of drug 


\begin{tabular}{|c|c|c|c|c|}
\hline \multirow{2}{*}{$\begin{array}{l}\text { TABLE } 3 \\
\text { Variable }\end{array}$} & \multirow[b]{2}{*}{ Levels } & \multirow[b]{2}{*}{$\begin{array}{c}\text { HIV+ve } \\
\text { prisoners } n\end{array}$} & \multirow[b]{2}{*}{$\begin{array}{c}\text { HIV-ve } \\
\text { prisoners } n\end{array}$} & \multirow[b]{2}{*}{$\begin{array}{c}\text { RR } \\
(95 \% \mathrm{Cl})\end{array}$} \\
\hline & & & & \\
\hline \multicolumn{5}{|l|}{ Clinical } \\
\hline \multirow[t]{2}{*}{ Losing weight } & Yes & 43 & 273 & $0.63(0.43-0.92)$ \\
\hline & No & 109 & 434 & \\
\hline \multirow[t]{2}{*}{ Fever } & Yes & 45 & 151 & $1.55(1.04-2.29)$ \\
\hline & No & 107 & 555 & \\
\hline \multirow[t]{2}{*}{ SOB } & Yes & 72 & 420 & $0.62(0.44-0.88)$ \\
\hline & No & 80 & 290 & \\
\hline \multirow[t]{2}{*}{ Previous lung disease } & Yes & 127 & 482 & $2.42(1.54-3.83)$ \\
\hline & No & 25 & 230 & \\
\hline \multirow[t]{2}{*}{ Chest pain } & Yes & 88 & 352 & $1.39(0.98-1.98)$ \\
\hline & No & 64 & 356 & \\
\hline \multicolumn{5}{|l|}{ Treatment types } \\
\hline \multirow{2}{*}{$\begin{array}{c}\text { Previously on } \\
\text { treatment }\end{array}$} & Yes & 96 & 382 & $1.44(1.00-2.06)$ \\
\hline & No & 57 & 326 & \\
\hline \multirow{2}{*}{$\begin{array}{l}\text { On anti-TB relapse } \\
\text { treatment }\end{array}$} & Yes & 18 & 34 & $2.61(1.43-4.75)$ \\
\hline & No & 136 & 670 & \\
\hline \multicolumn{5}{|l|}{$\begin{array}{l}\text { Previous medical } \\
\text { history }\end{array}$} \\
\hline \multirow[t]{2}{*}{ Liver disease } & Yes & 45 & 167 & $4.90(2.99-8.02)$ \\
\hline & No & 30 & 545 & \\
\hline \multicolumn{5}{|l|}{ Radiology } \\
\hline \multirow[t]{2}{*}{ Localised } & Yes & 37 & 157 & $2.12(1.35-3.33)$ \\
\hline & No & 56 & 504 & \\
\hline \multirow[t]{2}{*}{ Tuberculoma } & Yes & 12 & 29 & $3.96(1.93-8.12)$ \\
\hline & No & 66 & 631 & \\
\hline \multirow[t]{2}{*}{ Fibro-cavernous } & Yes & 19 & 76 & $2.15(1.23-3.77)$ \\
\hline & No & 68 & 585 & \\
\hline \multirow[t]{2}{*}{$\geqslant 2$ damaged zones } & Yes & 33 & 473 & $0.81(0.51-1.28)$ \\
\hline & No & 50 & 580 & \\
\hline \multirow{2}{*}{$\begin{array}{l}\geqslant 2 \text { damaged zones/ } \\
\text { cavities }\end{array}$} & Yes & 38 & 513 & $0.87(0.51-1.28)$ \\
\hline & No & 46 & 540 & \\
\hline \multicolumn{5}{|l|}{ TB contact } \\
\hline \multirow[t]{2}{*}{ Any contact } & Yes & 82 & 290 & $1.68(1.18-2.39)$ \\
\hline & No & 71 & 422 & \\
\hline $\begin{array}{l}\text { Social and sexual } \\
\text { history }\end{array}$ & & & & \\
\hline Alcohol & Yes & 146 & 641 & $2.34(1.06-5.20)$ \\
\hline & No & 7 & 72 & \\
\hline Jaundice & Yes & 46 & 45 & $6.38(4.03-10.10)$ \\
\hline & No & 107 & 668 & \\
\hline $\mathrm{HCV} / \mathrm{HBV}$ & Yes & 51 & 141 & $2.13(1.45-3.13)$ \\
\hline & No & 97 & 571 & \\
\hline Unprotected sex & Yes & 31 & 224 & $0.55(0.36-0.84)$ \\
\hline & No & 122 & 485 & \\
\hline Gonorrhoea & Yes & 15 & 41 & $1.80(0.97-3.35)$ \\
\hline & No & 135 & 665 & \\
\hline
\end{tabular}

+ve: positive; -ve: negative; RR: relative risk; Cl: confidence interval; SOB: shortness of breath; $\mathrm{HCV}$ : hepatitis $\mathrm{C}$ virus; HBV: hepatitis $\mathrm{C}$ virus

resistance. Standard doses of rifampicin have been low in previous Russian treatment guidelines [25, 26], with a discontinuation of treatment occurring at lower levels of liver function test abnormality than, for example, that which is recommended in UK and USA guidelines [27-31]. Prisoners will be released at the end of their sentence (as in Western European countries), and, if treatment is not completed, therapy will be continued in the civilian sector, although many patients are lost to follow-up. This, coupled with the reintroduction of therapy when repeat offenders are screened for TB fluorographically, contributes to the frequent "pulses" of inadequate chemotherapy.

Prisons (and pre-trial detention centres called SIZOs) are likely to be major drivers of the TB epidemic in Samara due to the following: 1) multiple partial treatment courses, as prisoners with TB had frequently been in prison several times; 2) the subsequent high loss to follow-up in the civilian sector, which has been reported elsewhere [1, 32, 33]; and 3) the existence of "perverse" incentives that discourage cure, such as better food, disability allowances and no work requirement whilst in the $\mathrm{TB}$ colony rather than in the main prison.

The system for ensuring continuity of TB therapy from prison to civilian sectors currently fails for the following reasons: 1) the address given by the prisoner might not be the intended destination; 2) there is a lack of incentives to attract exprisoners, unless they are highly symptomatic on release, into further institutional care, which is largely in-patient based; and 3) many prisoners are diagnosed with TB on admission from the SIZOs, suggesting that reducing the number of prisoners entering the penal system is as important as successfully treating those who leave it. A previous lack of unequivocal standardised treatment regimens and the reliance on in-patient therapy have encouraged the institutional spread of strains within institutions such as prisons and hospitals.

Several measures have now been undertaken at a regional level to address issues of emerging TB resistance, including the strengthening of bacteriological services, standardised World Health Organization/International Union Against Tuberculosis and Lung Disease treatment and outcome monitoring systems, increased ambulatory care, and improved prison-to-civilian interaction together with the provision of support to former prisoners. At a federal level, a new law covering all of Russia has been introduced [34]. This emphasises the importance of standardised regimens, uninterrupted drug supply, and bacteriological as well as radiological diagnosis. Today, only patients with smear-negative TB can be released early through amnesties. Recent changes in the Russian penal code have also led to a fall in those entering the SIZO system.

This study emphasises the importance of practical interventions to reduce the transmission of HIV targeted at individuals with high-risk behaviour, such as IDUs, including campaigns to reduce the spread of blood-borne viruses (e.g. needleexchange programmes). Information needs to be delivered in prisons to both inmates and administrators, as well as to IDUs outside. Although literacy rates in Samara (and in Russia as a whole) are high, there is anecdotal evidence that literacy is poor amongst many prisoners. Prisons need to improve literacy, particularly amongst teenage offenders, as part of any information campaign.

Prisons should be one of the main sites for HIV harmreduction activities, including needle exchange, provision of 
bleaches and condoms. Needle-exchange programmes are necessary, but politically difficult everywhere since this requires an admission that intravenous drug abuse is occurring within the prison, although STERN [13] has argued that prisons generally have individuals who use illegal drugs. The introduction of methadone programmes to both improve adherence of TB therapy in IDUs and prisoners, as well as directly observed TB therapy, has been shown to be successful and useful in preventing the transmission of HIV in congregated settings in other countries, such as Spain [35].

It is reasonable to conclude that imprisonment is contributing to both HIV and TB epidemics in the Samara region and, by implication, in Russia as a whole. Multiple incomplete treatment cycles, particularly in prisoners, with frequent loss to follow-up when discharged lead to drug resistance and low cure rates in TB patients. Intravenous drug abuse, in particular, is spreading blood-borne viruses. By systematically analysing the population over a 1-yr period, coupled with the high response rate, the current authors believe that this study has produced a definitive evidence base on which health-policy changes can be established. Greater coordination and integration between traditionally vertical TB and HIV programmes with a combined medical, social and behavioural approach would facilitate the management of both diseases.

Worldwide, prisons are full of marginalised people often living in overcrowded conditions, but prison health impacts on civil society when prisoners are released. Improvements in healthcare in prisons are likely to be of benefit to all.

\section{ACKNOWLEDGEMENTS}

The authors would like to thank the staff and directors of the Moscow Federal Central Tuberculosis Research Institute and Research Institute for Physiopulmonology, and Samara Regional TB service dispensaries and hospitals for their valuable advice and support in the design and implementation of the study. The authors are particularly grateful to the doctors, nurses and patients who took part in the study.

\section{REFERENCES}

1 UNAIDS report for 2003: most deaths and new infections ever; some good news. AIDS Treat News 2003; 396: 3.

2 Pokrovsky VV, Ladnaia NN, Buratsova EB, Sokolova EV. HIV infection surveillance in Russia in 2001. Moscow, Russian Federal AIDS Centre Update, 2002.

3 Drobniewski FA, Balabanova YM. The diagnosis and management of multiple-drug-resistant-tuberculosis at the beginning of the new millenium. Int J Infect Dis 2002; 6: Suppl. 1, S21-S31.

4 Shilova MV, Dye C. The resurgence of tuberculosis in Russia. Philos Trans R Soc Lond B Biol Sci 2001; 356: 1069-1075.

5 Erokhin VV, Demikhova OV, Punga VV, Putova EV. New organisational forms of antituberculosis care under present conditions. Results and experience exchange of work in pilot regions. Scientific-and-Practical Conference (Moscow, September 25-27, 2002). Probl Tuberk 2003; 2: 48-50.

6 Drobniewski FA. Multiple-drug-resistant tuberculosis. Lancet 2000; 356: Suppl., s62.
7 Drobniewski FA, Pozniak AL. Molecular diagnosis, detection of drug resistance and epidemiology of tuberculosis. Br J Hosp Med 1996; 56: 204-208.

8 Narvskaia OV, Vishnevskii BI, El'kin AV, et al. Molecular genetic characteristics of Mycobacterium tuberculosis isolated from patients operated on for pulmonary tuberculosis. Probl Tuberk 2002; 3: 50-53.

9 Toungoussova S, Caugant DA, Sandven P, Mariandyshev AO, Bjune G. Drug resistance of Mycobacterium tuberculosis strains isolated from patients with pulmonary tuberculosis in Archangels, Russia. Int $J$ Tuberc Lung Dis 2002; 6: 406-414.

10 Spradling P, Nemtsova E, Aptekar T, et al. Anti-tuberculosis drug resistance in community and prison patients, Orel Oblast, Russian Federation. Int J Tuberc Lung Dis 2002; 6: 757-762.

11 Kruuner A, Hoffner SE, Sillastu H, et al. Spread of drugresistant pulmonary tuberculosis in Estonia. J Clin Microbiol 2001; 39: 3339-3345.

12 Drobniewski FA, Atun R, Fedorin I, Bikov A, Coker R. The "bear trap": the colliding epidemics of tuberculosis and HIV in Russia. Int J STD AIDS 2004; 15: 641-646.

13 Stern V. Problems in prisons worldwide, with a particular focus on Russia. Ann N Y Acad Sci 2001; 953: 113-119.

14 Coyle A, Stern V. Prison health and public health: the integration of prison health services. Report from a conference. London, Dept of Health and International Centre for Prison Studies, 2004.

15 Stern V. "Tuberculosis among prisoners". Report from the Second Interdisciplinary Expert Meeting on Prevention and Control in the Baltic Sea Region. Task Force for the control of communicable diseases in the Baltic Sea states. St. Petersburg, Council of the Baltic Sea states, 2002.

16 Samara AIDS Center Epidemiological Update. Samara, Samara Ministry of Health, 2004.

17 Rhodes T, Lowndes C, Judd A, et al. Explosive spread and high prevalence of HIV infection among injecting drug users in Togliatti City, Russian. AIDS 2002; 16: F25-F31.

18 Coker R, Dimitrova B, Drobniewski F, et al. Tuberculosis control in Samara Oblast, Russia: institutional and regulatory environment. Int J Tuberc Lung Dis 2003; 7: 920-932.

19 Samara TB Service Annual Report. Samara, Samara Ministry of Health, 2002.

20 Copas AJ, Wellings K, Erens B, et al. The accuracy of reported sensitive sexual behaviour in Britain: exploring the extent of change 1990-2000. Sex Transm Infect 2002; 78: 26-30.

21 Johnson AM, Mercer CH, Erens B, et al. Sexual behaviour in Britain: partnerships, practices, and HIV risk behaviours. Lancet 2001; 358: 1835-1842.

22 Power R, Nozhkina N. The value of process evaluation in sustaining HIV harm reduction in the Russian Federation. AIDS 2002; 16: 303-304.

23 Drobniewski F, Balabanova Y, Ruddy M, et al. Rifampinand multidrug-resistant tuberculosis in Russian civilians and prison inmates: dominance of the beijing strain family. Emerg Infect Dis 2002; 8: 1320-1326.

24 Ruddy M, Balabanova Y, Graham C, et al. Rates of drug resistance and risk factor analysis in civilian and prison patients with tuberculosis in Samara Region, Russia. Thorax 2005; 60: 130-135. 
25 Drobniewski F, Tayler E, Ignatenko N, et al. Tuberculosis in Siberia: 1. An epidemiological and microbiological assessment. Tuber Lung Dis 1996; 77: 199-206.

26 Coker R. Control of tuberculosis in Russia. Lancet 2001; 358: 434-435.

27 Control and prevention of tuberculosis in the United Kingdom: Code of Practice 1994. Joint Tuberculosis Committee of the British Thoracic Society. Thorax 1994; 49: 1193-1200.

28 New UK guidance on the prevention and control of transmission of HIV related and drug resistant tuberculosis. Commun Dis Rep CDR Wkly 1999; 9: 49.

29 Hurtig AK, Porter JD, Ogden JA. Tuberculosis control and directly observed therapy from the public health/human rights perspective. Int J Tuberc Lung Dis 1999; 3: 553-560.

30 Davies PD. Comparison of international guidelines on the control and prevention of tuberculosis. Monaldi Arch Chest Dis 2001; 56: 74-78.
31 White VL, Paliwalla M, Steves CJ, Jadhav D, MooreGillon J. Management of tuberculosis in a British inner-city population. J Public Health Med 2002; 24: $49-52$.

32 Coker RJ, Dimitrova B, Drobniewski F, et al. Tuberculosis control in Samara Oblast, Russia: institutional and regulatory environment. Int J Tuberc Lung Dis 2003; 7: 920-932.

33 Coker R. Detention and mandatory treatment for tuberculosis patients in Russia. Lancet 2001; 358: 349-350.

34 Prikaz 109 Russian Ministry of Health. Prikaz on Improving of Tuberculosis Control Activities in the Russian Federation. Moscow, Ministry of Health, 2003.

35 Marco A, Cayla JA, Serra M, et al. Predictors of adherence to tuberculosis treatment in a supervised therapy programme for prisoners before and after release. Study Group of Adherence to Tuberculosis Treatment of Prisoners. Eur Respir J 1998; 12: 967-971. 